Sains Malaysiana 49(12)(2020): 3117-3123

http://dx.doi.org/10.17576/jsm-2020-4912-24

\title{
Cobalt Sulfide as Photoelectrode of Photoelectrochemical Hydrogen Generation from Water
}

(Kobalt Sulfida sebagai Fotoelektrod untuk Penjanaan Hidrogen Fotoelektrokimia daripada Air)

\author{
Mustafid Amna Rambey, Khuzaimah Arifin*, Lorna Jeffery Minggu \& Mohammad B. Kassim
}

\begin{abstract}
This study aimed to synthesize and characterize cobalt sulfide deposited on FTO by hydrothermal method and investigate its photoelectrochemical (PEC) water splitting performance. Cobalt sulfide thin films were produced by annealing at two different temperatures, namely, 400 and $500^{\circ} \mathrm{C}$. X-ray diffraction (XRD) and Fourier transform Raman spectroscopy were used to characterize the phase structure. Scanning electron microscopy was used to observe the morphology. Ultraviolet-visible spectroscopy and linear sweep voltammetry analyses were used to determine the thinfilm band gap and evaluate the PEC water splitting performance, respectively. From the XRD and Raman analyses, all the samples produced consisted of mixed phases of $\mathrm{Co}_{3} \mathrm{~S}_{4}$ and $\mathrm{Co}_{9} \mathrm{~S}_{8}$. However, each sample contained different percentage phases. The sample annealed at $400{ }^{\circ} \mathrm{C}$ contained more $\mathrm{Co}_{9} \mathrm{~S}_{8}$, whereas that annealed at $500{ }^{\circ} \mathrm{C}$ contained comparable amounts of $\mathrm{Co}_{3} \mathrm{~S}_{4}$ and $\mathrm{Co}_{9} \mathrm{~S}_{8}$. The morphologies of pre-annealed samples showed vertical flakes with diameters around 200-250 $\mathrm{nm}$ and flake thickness around 25-50 $\mathrm{nm}$. When the temperature was increased from preannealing temperature to 400 and $500^{\circ} \mathrm{C}$, several flakes were destructed and formed spherical-like clusters. The Tauc plot from absorption analysis showed that the samples annealed at 400 and $500^{\circ} \mathrm{C}$ produced similar band gaps at $\sim 2.0$ $\mathrm{eV}$. The PEC performance analysis results show that annealing at $400^{\circ} \mathrm{C}$ produced the highest photocurrent density of $10 \mu \mathrm{A} / \mathrm{cm}^{2}$ at a potential of $-0.7 \mathrm{~V}$.
\end{abstract}

Keywords: Cobalt sulphide; hydrogen production; hydrothermal; photoelectrochemical

ABSTRAK

Kajian ini bertujuan untuk mensintesis dan mencirikan kobalt sulfida yang dimendapkan pada FTO dengan kaedah hidrotermal dan mengkaji keupayaannya untuk pemisahan air fotoelektrokimia (PEC). Filem nipis kobalt sulfida yang terhasil disepuhlindap pada dua suhu yang berbeza, iaitu: 400 dan $500{ }^{\circ} \mathrm{C}$. Analisis pembelauan sinar-X (XRD) dan spektroskopi transformasi Fourier Raman (Raman) digunakan untuk mencirikan struktur fasa. Mikroskopi elektron imbasan (SEM) digunakan untuk memerhatikan morfologi. Analisis spektroskopi ultraungu-nampak (UV-Vis) dan voltametri kilasan linear digunakan untuk menentukan sela jalur dan menilai prestasi pemisahan air PEC filem nipis tersebut. Daripada analisis XRD dan Raman, semua filem nipis yang dihasilkan terdiri daripada fasa campuran $\mathrm{Co}_{3} \mathrm{~S}_{4}$ dan $\mathrm{Co}_{9} \mathrm{~S}_{8}$. Walau bagaimanapun, filem nipis tersebut berisi peratusan fasa yang berbeza. Filem nipis yang disepuhlindap pada suhu $400{ }^{\circ} \mathrm{C}$ berisi lebih banyak $\mathrm{Co}_{9} \mathrm{~S}_{8}$, sedangkan yang disepuhlindap pada $500{ }^{\circ} \mathrm{C}$ berisi jumlah $\mathrm{Co}_{3} \mathrm{~S}_{4}$ dan $\mathrm{Co}_{9} \mathrm{~S}_{8}$ yang lebih berimbang. Morfologi sampel pra-sepuhlindap menunjukkan kepingan menegak dengan diameter 200-250 nm dan ketebalan 25-50 nm. Selepas suhu dinaikkan daripada suhu pra-sepuhlindap kepada 400 dan $500{ }^{\circ} \mathrm{C}$, beberapa kepingan hancur dan membentuk gumpalan seperti sfera. Plot Tauc daripada analisis penyerapan menunjukkan bahawa filem nipis disepuhlindap pada suhu 400 dan $500{ }^{\circ} \mathrm{C}$ menghasilkan sela jalur yang hampir sama $\sim 2.0 \mathrm{eV}$. Hasil analisis prestasi PEC mendapati bahawa filem nipis disepuhlindap pada suhu $400{ }^{\circ} \mathrm{C}$ mempunyai ketumpatan arus tertinggi sebesar $10 \mu \mathrm{A} / \mathrm{cm}^{2}$ pada potensi $-0,7 \mathrm{~V} v \mathrm{Ag} / \mathrm{AgCl}$.

Kata kunci: Fotoelektrokimia; hidroterma; kobalt sulfida; pengeluaran hidrogen

\section{INTRODUCTION}

The transformation of the global energy system shows a strong change in energy from fossil fuels to hydrogen (Staffell et al. 2019). The main challenges among the driving forces that lead to the transition of energy toward hydrogen include the energy requirements, oil shortages in the coming years, and the prospect of global warming. By 2050, energy consumption is projected to increase for a global population of 10 billion people (Boretti \& Rosa 2019). Coal and oil are great sources of energy, but we also 
need other energy sources that are notably larger and can meet future energy needs (Gielen et al. 2019). Hydrogen production from water molecules using sunlight energy is considered a good alternative to the provision of renewable energy; it is environmentally friendly, thus, can serve as a suitable bridge between supply and demand (Adnan et al. 2018). Photoelectrochemical (PEC) water splitting is widely recognized as one of the most promising means for large-scale hydrogen production in the future since the investigation by Fujishima and Honda in 1972 (Sathre et al. 2016).

PEC water splitting needs semiconductor materials as photoelectrode. A photoelectrode immersed in waterbased electrolyte and exposed to light will generate separated electrons and holes at the semiconductor surface ( $\mathrm{Ng}$ et al. 2017). The photogenerated charge carrier then participates in water oxidation/reduction (Hisatomi et al. 2014). Several requirements are required for semiconductor materials to be used as photoelectrodes, that is, the semiconductor band gap should be above the thermodynamic potential of water splitting $1.23 \mathrm{eV}$ and below $3.0 \mathrm{eV}$ to absorb the full range of visible-light energy. In addition, the valence band and conduction band positions should be straddled to water oxidation and reduction potentials (Salehmin et al. 2019). Furthermore, the semiconductor should be photo- and chemically stable and inexpensive. Titanium dioxide $\left(\mathrm{TiO}_{2}\right)$ was the first semiconductor material to be investigated, and to date, this material is still worthy of investigation because it is photoactive, stable against photocorrosion, abundant, and cheap. However, $\mathrm{TiO}_{2}$ exhibits an extremely low PEC performance due to its large band gap, which causes the easy recombination of photogenerated products (electrons and holes). Considerable works, including the development of heterojunction composites with other active and stable materials, were conducted to improve the PEC water splitting performance. Metal chalcogenide semiconductors, such as CdS that has a direct band gap of $\sim 2.0 \mathrm{eV}$ and is an excellent visible-light-responsive material, are one of the widely investigated materials (Rosman et al. 2018). The use of CdS to sensitize $\mathrm{TiO}_{2}$ increases the photocurrent of $\mathrm{TiO}_{2}$ from $0.22 \mathrm{~mA} / \mathrm{cm}^{2}$ to $7.82 \mathrm{~mA} / \mathrm{cm}^{2}$, indicating a 35 -time improvement (Sun et al. 2008). However, CdS is highly toxic and is a photocorrosion material that is difficult to handle (Cheng et al. 2018). The investigation of other materials that have similar properties to $\mathrm{CdS}$ is a new challenge; such studies should focus on the use of cobalt-based materials such as cobalt sulfide.

Cobalt sulfide is an interesting material because its Co-S bond has several forces and binding mechanisms that can form ionic, covalent, and metal bonds in molecules to form several phases, such as $\mathrm{Co}_{4} \mathrm{~S}_{3}, \mathrm{Co}_{9} \mathrm{~S}_{8}, \mathrm{CoS}, \mathrm{Co}_{1}-$ $\mathrm{xS}, \mathrm{Co}_{3} \mathrm{~S}_{4}, \mathrm{Co}_{2} \mathrm{~S}_{3}$, and $\mathrm{CoS}_{2}$ (Pawar \& Garje 2015). $\mathrm{CoS}_{2}$ is a good electrode in alkaline electrolyzer application.
Ma et al. (2018) reported that $\mathrm{CoS}_{2}$ hollow nanosphere electrode achieved a faradaic efficiency of $100 \%$ and 10 $\mathrm{mA} / \mathrm{cm}^{2}$ at a low cell voltage of $1.54 \mathrm{~V}$ at $60^{\circ} \mathrm{C}$ and exhibits long-term catalytic durability compared with $\mathrm{RuO}_{2}$ and $\mathrm{Pt} / \mathrm{C}$ electrodes. However, the studies on cobalt sulfide as a photoelectrode for water splitting are limited. Wang et al. (2019) used CoS as a component in a multi-junction with $\mathrm{Cu}(\mathrm{In}, \mathrm{Ga}) \mathrm{SSe}$ (CIGS) thin films, which produced a remarkable photocurrent density of $19.1 \mathrm{~mA} / \mathrm{cm}^{2}$ at $-0.34 \mathrm{~V}$ versus reversible hydrogen electrode. The presence of $\mathrm{CoS}$ as a catalyst in the composite improved the CIGS performance compared when Pt was used as the catalyst (Wang et al. 2019).

In general, cobalt sulfide can be synthesized using low-cost methods, such as sonochemical (Kristl et al. 2017; Muradov et al. 2018), hydrothermal (Chen et al. 2016; Wang et al. 2017), successive ionic layer adsorption and reaction (SILAR) (Kale et al. 2020), and electrodeposition (Nan et al. 2018) methods. Cobalt sulfide is also known as a temperature-dependent material; it produces different phases if annealed at various temperatures (Moridon et al. 2019). The comparable study of the PEC performance of each phase has not been reported. In this study, cobalt sulfide was prepared directly on fluorine-doped tin oxide (FTO) using a hydrothermal method and then annealed at two different temperatures $\left(400\right.$ and $\left.500{ }^{\circ} \mathrm{C}\right)$. The phase structure was analyzed using X-ray diffraction (XRD) and Fourier transform Raman spectroscopy (FT-Raman). The morphologies were studied by scanning electron microscopy (SEM). Meanwhile, the band gap of the thin films was determined from the Tauc plot of the ultraviolet-visible (UV-Vis) data. The performance of the thin films as photoelectrode was evaluated based on the photocurrent by linear sweep voltammetry (LSV) measurement in an acid solution.

\section{MATERIALS AND METHODS}

\section{MATERIALS}

Cobalt nitrate hexahydrate $\mathrm{Co}\left(\mathrm{NO}_{3}\right)_{2} \cdot 6 \mathrm{H}_{2} \mathrm{O}$, thiourea (NH4)2S (analytical grade), $\mathrm{H}_{2} \mathrm{SO}_{4}$ ACS reagent (98.0\%), polyethylene glycol, and fluorine-doped tin oxide (FTO) were purchased from Sigma-Aldrich. Ethanol was purchased from Chem-Supply. All chemicals were used as received without further purification.

\section{FTO/COBALT SULFIDE PREPARATION}

The FTO $(3 \mathrm{~cm} \times 3 \mathrm{~cm} \times 2 \mathrm{~mm})$ glasses were cleaned with acetone, ethanol, and deionized water for $0.5 \mathrm{~h}$ each and dried with nitrogen. A total of $5 \mathrm{~mL}$ deionized water and $20 \mathrm{~mL}$ ethyl alcohol were stirred at room temperature for $0.5 \mathrm{~h}$. Then, $\mathrm{Co}\left(\mathrm{NO}_{3}\right)_{3} \cdot 6 \mathrm{H}_{2} \mathrm{O}(1.46 \mathrm{~g})$ and $\left(\mathrm{NH}_{4}\right)_{2} \mathrm{~S}(0.38$ g) were added to this above solution. The mixture was continuously stirred for $0.5 \mathrm{~h}$ and ultrasonicated for 0.5 
$\mathrm{h}$ to obtain a well-mixed solution. The mixture was poured into a Teflon-lined autoclave containing vertically placed FTO glass substrate and partially immersed in the solution and heated at $180^{\circ} \mathrm{C}$ for $12 \mathrm{~h}$. The autoclave was left to cool to room temperature. Then, the thin films were retrieved from the autoclave and washed thrice with distilled water and ethanol to remove unbound impurities. The black, thin films were then dried overnight in an oven at $60{ }^{\circ} \mathrm{C}$, followed by annealing at 400 and $500{ }^{\circ} \mathrm{C}$.

\section{CHARACTERIZATIONS}

XRD patterns were obtained using Bruker D-8 Advance to identify the chemical phase present in the crystalline material. SEM was conducted on a Zeiss Merlin Compact to observe the topographic surface. The optical properties of the thin films were analyzed on a Perkin Elmer Lambda 950 equipped with a diffuse reflectance spectrophotometer. The spectra collected were then converted into Kubelka-Munk function $F(R)$ versus the wavelength to identify the sample band gap.

\section{PEC MEASUREMENT}

PEC water splitting analysis was conducted using an Ametek Versastat 4 and an electrochemical cell using a three-electrode system. The thin films used as working electrodes were tested in a designed photocell with an exposed area of $1 \mathrm{~cm}^{2}$. A platinum wire was utilized as a counter electrode, and an $\mathrm{Ag} / \mathrm{AgCl}$ electrode was used as the reference electrode. The scan rate for LSV was 5 $\mathrm{mV} \mathrm{s}^{-1}$. Photocurrent irradiation was measured by an XW 300W lamp (PLS-SXE300, PE300BF) equipped with a $1.5 \mathrm{G}$ AM filter and light source intensity calibrated with Si diode (Model 818, Newport) to simulate 1.5G AM lighting $\left(100 \mathrm{~mW} / \mathrm{cm}^{2}\right)$.

\section{RESULTS AND DISCUSSION}

Figure 1(A) shows the XRD pattern of the pre-annealed samples and those annealed at 400 and $500{ }^{\circ} \mathrm{C}$. The XRD patterns of three separate samples can be indexed to the $\mathrm{Co}_{9} \mathrm{~S}_{8}$ mixing phase (PDF No. 65-6801) and $\mathrm{Co}_{3} \mathrm{~S}_{4}$ (PDF No. 47-1738), suggesting the formation of $\mathrm{Co}_{9} \mathrm{~S}_{8}$ and $\mathrm{Co}_{3} \mathrm{~S}_{4}$, respectively. The peaks of all samples at $2 \theta=$ $33.7^{\circ}, 37.7^{\circ}$ can be classified to those of FTO glass. The peaks at $26.5^{\circ}$ and $55^{\circ}$ can be attributed to $\mathrm{Co}_{3} \mathrm{~S}_{4}$, whereas those at $33.7^{\circ}$ and $51.4^{\circ}$ were attributed to the (222) and (440) diffractions of $\mathrm{Co}_{9} \mathrm{~S}_{8}$, respectively. The XRD patterns showed that the pre-annealed samples and those annealed at $500{ }^{\circ} \mathrm{C}$ contained more $\mathrm{Co}_{3} \mathrm{~S}_{4}$ compared with the sample annealed at $400^{\circ} \mathrm{C}$. Meanwhile, the sample annealed at 400 ${ }^{\circ} \mathrm{C}$ almost produced a single phase of $\mathrm{Co}_{9} \mathrm{~S}_{8}$, with small peak of $\mathrm{Co}_{3} \mathrm{~S}_{4}$ at $2 \theta=55.2^{\circ}$.
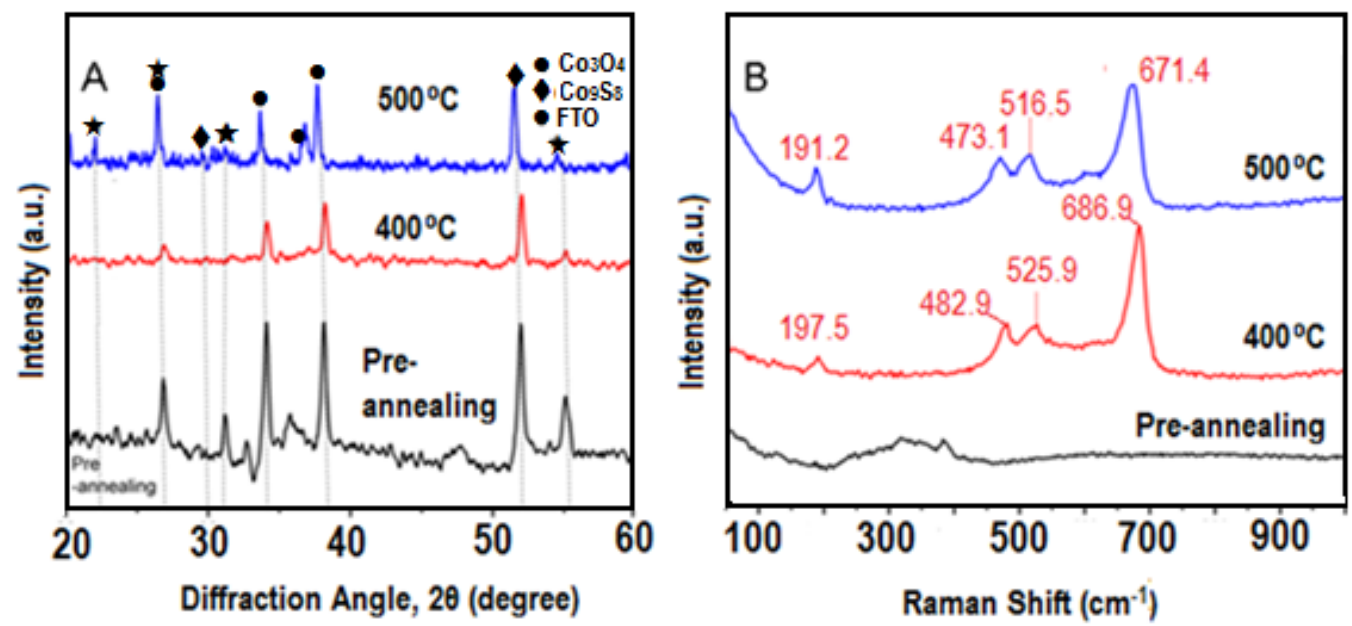

FIGURE 1. (A) XRD patterns of the pre-annealed sample $\left(60^{\circ} \mathrm{C}\right)$ and those annealed at 400 and $500{ }^{\circ} \mathrm{C}$ for $2 \mathrm{~h}$, (B) Raman spectra of the pre-annealed samples $\left(60^{\circ} \mathrm{C}\right)$ and those annealed at 400 and $500{ }^{\circ} \mathrm{C}$ for $2 \mathrm{~h}$

\section{PHASE AND CRYSTALLINITY ANALYSIS}

The XRD results were supported by the FT-Raman spectra (Figure 1(B)), which showed that all samples annealed at 400 and $500{ }^{\circ} \mathrm{C}$ exhibited Raman peaks at 450 and $750 \mathrm{~cm}^{-1}$ and were indexed to $\mathrm{Co}_{3} \mathrm{~S}_{4}$ and $\mathrm{Co}_{9} \mathrm{~S}_{8}$, respectively. The Raman spectral patterns were compatible with previously reported results for cobalt sulfide by Lei et al. (2012). The spectrograms of the sample showed an amorphous structure with broad Raman peaks for the pre-annealed sample compared with those annealed at 400 and $500{ }^{\circ} \mathrm{C}$ (Figure 1(B)). 

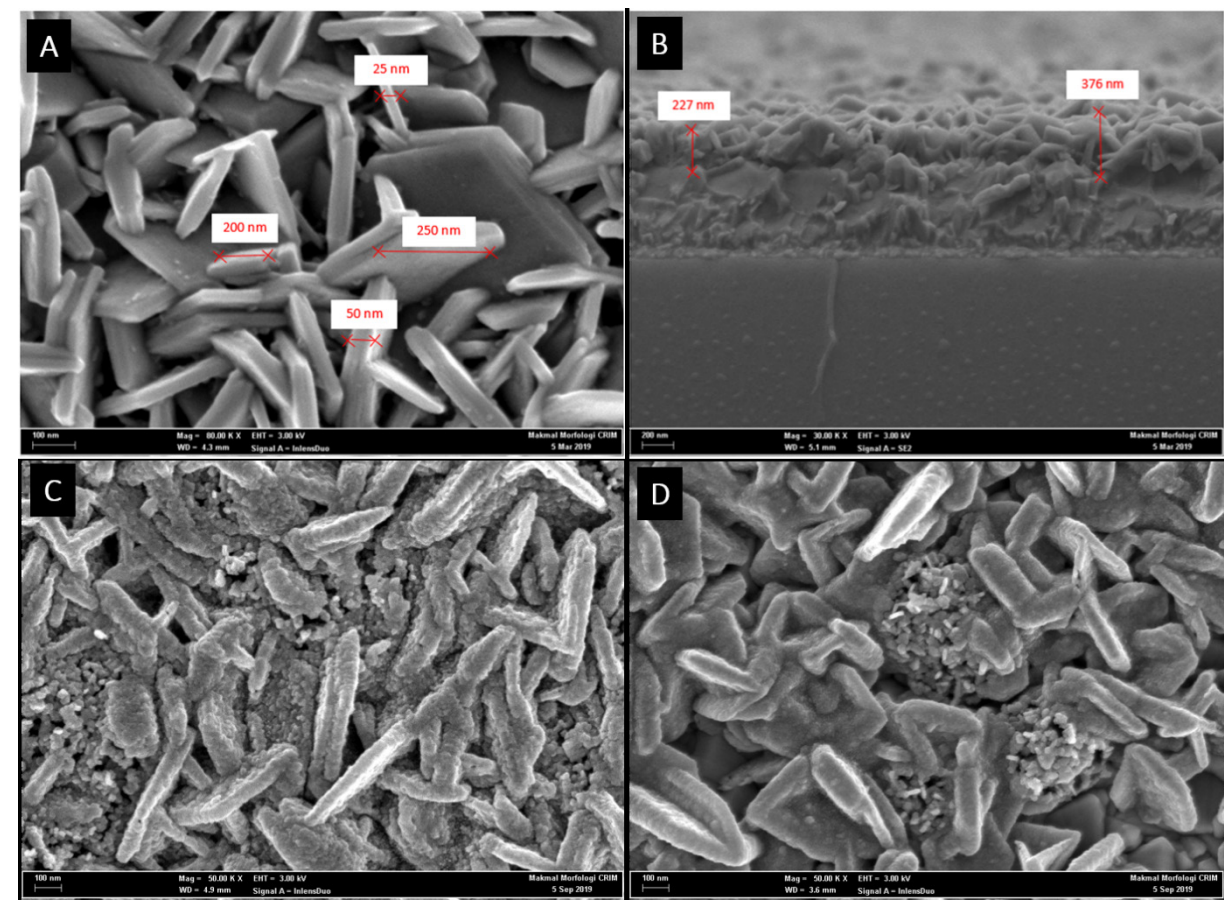

FIGURE 2. SEM surface morphology of CoxSy deposited on FTO

(A) pre-annealing, (B) cross section thickness of pre-annealing, (C-D) sample annealed 400 and $500{ }^{\circ} \mathrm{C}$, respectively

\section{STRUCTURAL AND MORPHOLOGICAL ANALYSIS}

The morphologies of pre-annealed samples and those annealed at 400 and $500{ }^{\circ} \mathrm{C}$ were determined using SEM. Figure 2(A) present the morphologies of the pre-annealed sample, which showed vertical flakes with diameters around 200-250 nm and flake thickness around $25-50 \mathrm{~nm}$. While the film thickness produced is around 227-376 nm, quite thin (Figure 2(B)). Referring to the work of Yin et al. (2008), the flakes were representative of $\mathrm{Co}_{9} \mathrm{~S}_{8}$. When the temperature was increased from preannealing temperature to 400 and $500{ }^{\circ} \mathrm{C}$, several flakes were destructed and formed spherical-like clusters (Liu et al. 2016; Yin et al. 2008) (Figure 2(C)-2(D)). The SEM results indicate that annealing temperature influences the organization and structure of cobalt sulfides.

\section{OPTICAL AND PHOTOELECTROCHEMICAL PROPERTIES}

Figure 3(A) displays the absorption of cobalt sulfide thin films and shows that cobalt sulfide with annealing treatment had increased absorption intensity of UV region compared with the pre-annealed sample. All the samples showed the strongest absorption at $300 \mathrm{~nm}$ which is absorption of FTO to the light (In \& Lee 2012). A strong and broad peak absorption of the samples appeared at the visible region, with the sample annealed at $400{ }^{\circ} \mathrm{C}$ absorb at slightly higher wavelength position than that annealed at $500{ }^{\circ} \mathrm{C}$. The optical properties were studied by UV-Vis spectroscopy data using the Tauc method based on the assumption that the energy-dependent absorption coefficient $\alpha$ can be expressed by the following equation (Makuła et al. 2018):

$$
(\alpha . h v)^{1 / 2}=B\left(h v-E_{g}\right)
$$

where h is Planck's constant; is the photon's frequency; Eg is the band-gap energy; and B is a constant. The measured reflectance spectra were transformed into absorption spectra by applying the Kubelka-Munk function $\left(\mathrm{F}\left(\mathrm{R}_{\infty}\right)\right.$,

$$
\left(F\left(R_{\infty}\right) \cdot h v\right)^{1 / 2}=B\left(h v-E_{g}\right)
$$

Figure 3(B) shows the Tauc plot for the band gap determination. The sample annealed at $400{ }^{\circ} \mathrm{C}$ had a band gap around $2 \mathrm{eV}$, whereas that annealed at $500^{\circ} \mathrm{C}$ had a band gap of $1.9 \mathrm{eV}$. The decrease in band gap can be attributed to the formation of $\mathrm{Co}_{3} \mathrm{~S}_{4}$ with the increase in annealing temperature from 400 to $500{ }^{\circ} \mathrm{C}$.

Figure 3(C) displays the LSV measurements of the samples in light and dark conditions. The preannealed samples and those annealed at $500{ }^{\circ} \mathrm{C}$ were photoelectrochemically inactive against light radiation 

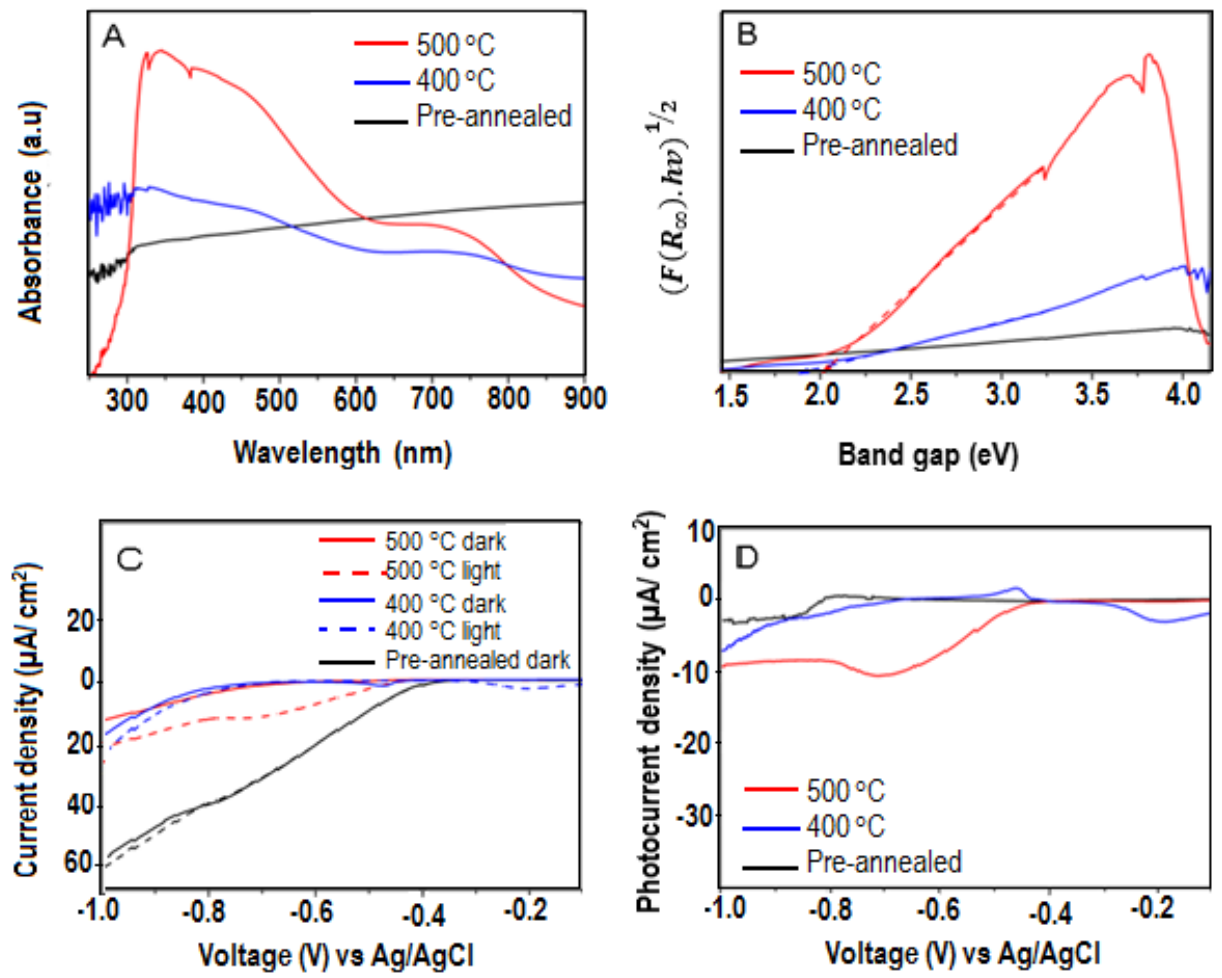

FIGURE 3. (A) UV-Vis absorption spectra, and (B) Tauc plot of the band-gap energy of various samples, (C) PEC measurements for cobalt sulfide deposited on FTO: LSV under

light and dark conditions, (D) Photocurrent density vs. applied potential graph

and showed no significant difference between dark and light currents. LSV measurement result shows that both dark and light currents all the samples produce high current density, it means this material more suitable used as an electrocatalyst for hydrogen evolution reaction (HER). The sample annealed at $400{ }^{\circ} \mathrm{C}$ exhibited a photocurrent density of $10 \mu \mathrm{A} / \mathrm{cm}^{2}$ at $-0.7 \mathrm{~V}$ versus $\mathrm{Ag} / \mathrm{AgCl}$. Furthermore, the sample annealed at $400{ }^{\circ} \mathrm{C}$ (Figure 3(D)) showed a high photocurrent density of $5 \mu \mathrm{A} / \mathrm{cm}^{2}$ at -0.2 $\mathrm{V}$. However, the photocurrent decreased at high potentials and increased again to $5 \mu \mathrm{A} / \mathrm{cm}^{2}$ at $-1.0 \mathrm{~V}$. The annealed samples produced different peaks of potential reduction, which can be related to their mixed-phase content. Based on the XRD results, the intensity of $\mathrm{Co}_{3} \mathrm{~S}_{4}$ was higher in the sample annealed at $500{ }^{\circ} \mathrm{C}$ compared with that annealed at $400{ }^{\circ} \mathrm{C}$. Thus, the sample annealed at $500{ }^{\circ} \mathrm{C}$ contained more $\mathrm{Co}_{3} \mathrm{~S}_{4}$ than that annealed at $400{ }^{\circ} \mathrm{C}$. Meanwhile, $\mathrm{Co}_{9} \mathrm{~S}_{8}$ was the majority phase in the sample annealed at 400 ${ }^{\circ} \mathrm{C}$. Thus, the $\mathrm{Co}_{9} \mathrm{~S}_{8}$ phase of cobalt sulfides is more active in photocatalytic water splitting compared with $\mathrm{Co}_{3} \mathrm{~S}_{4}$ at a high bias potential. Meanwhile, $\mathrm{Co}_{3} \mathrm{~S}_{4}$ is more active at low bias potentials although the photocurrent achieved by $\mathrm{Co}_{3} \mathrm{~S}_{4}$ is lower than that by $\mathrm{Co}_{9} \mathrm{~S}_{8}$. The results of LSV shows that the cobalt sulfide produces high current density, but low photocurrent. It means that the cobalt sulfide more suitable used as an electrocatalyst for water electrolysis rather than as a photocatalyst or photoelectrocatalyst. The cobalt sulfide has been reported as one of the remarkable catalysts in alkaline electrolyzer as reported by many researcher (Nan et al. 2018; Sultana et al. 2017).

\section{CONCLUSION}

Cobalt sulfide $\left(\mathrm{Co}_{\mathrm{x}} \mathrm{S}_{\mathrm{y}}\right)$ thin films were produced by hydrothermal methods at three annealing temperatures. Phase and morphological analyses confirmed that all the samples consisted of $\mathrm{Co}_{9} \mathrm{~S}_{8}$ and $\mathrm{Co}_{3} \mathrm{~S}_{4}$ mixed phases. Based on $\mathrm{XRD}$ results, the sample annealed at $500{ }^{\circ} \mathrm{C}$ contained more $\mathrm{Co}_{3} \mathrm{~S}_{4}$ than that annealed at $400{ }^{\circ} \mathrm{C}$, actively splitting water molecules at low bias potentials. Meanwhile, the sample annealed at $400{ }^{\circ} \mathrm{C}$ contained more $\mathrm{Co}_{9} \mathrm{~S}_{8}$ than $\mathrm{Co}_{3} \mathrm{~S}_{4}$ active phases, splitting water molecules at high bias potentials. The cobalt sulfide annealed at $400^{\circ} \mathrm{C}$ produced the highest photocurrent density (approximately $10 \mu \mathrm{A}$ $\mathrm{cm}^{2}$ ) at $-0.7 \mathrm{~V}$ versus $\mathrm{Ag} / \mathrm{AgCl}$. This study showed that $\mathrm{Co}_{9} \mathrm{~S}_{8}$ and $\mathrm{Co}_{3} \mathrm{~S}_{4}$ exhibit different redox potentials to split 
water molecules. Besides that, from the LSV measurement, both dark and light currents produce high current density, that means the cobalt sulfide material more suitable used as an electrocatalyst for hydrogen evolution reaction (HER) rather than as a photocatalyst or photoelectrocatalyst for water splitting.

\section{ACKNOWLEDGEMENTS}

This research was funded by the Ministry of Higher Education, Malaysia under Fundamental Research Grant Scheme FRGS/1/2019/STG01/UKM/03/2; Universiti Kebangsaan Malaysia for Publication Acceleration Fund PP-SELFUEL-2020.

\section{REFERENCES}

Adnan, M.A.B., Arifin, K., Minggu, L.J. \& Kassim, M.B. 2018. Titanate-based perovskites for photochemical and photoelectrochemical water splitting applications: A review. International Journal of Hydrogen Energy 43(52): 2320923220.

Boretti, A. \& Rosa, L. 2019. Reassessing the projections of the world water development report. npj Clean Water 2(15): 1-6.

Chen, Z., Wan, Z., Yang, T., Zhao, M., Xingyan, Lv., Wang, H., Ren, X. \& Mei, X. 2016. Preparation of nickel cobalt sulfide hollow nanocolloids with enhanced electrochemical property for supercapacitors application. Scientific Reports 6(25151): 1-8.

Cheng, L., Xiang, Q., Liao, Y. \& Zhang, H. 2018. CdS-based photocatalysts. Energy \& Environmental Science 11(6): 1362-1391.

Fujishima, A. \& Honda, K. 1972. Electrochemical photolysis of water at a semiconductor electrode. Nature 238: 37-38.

Gielen, D., Boshell, F., Saygin, D., Bazilian, M.D., Wagner, N. \& Gorini, R. 2019. The role of renewable energy in the global energy transformation. Energy Strategy Reviews 24: 38-50.

Hisatomi, T., Kubota, J. \& Domen, K. 2014. Recent advances in semiconductors for photocatalytic and photoelectrochemical water splitting. Chemical Society Reviews 43(22): 7520-7535.

In, S.I. \& Lee, H.S. 2012. Low temperature synthesis of transparent, vertically aligned anatase $\mathrm{TiO}_{2}$ nanowire arrays: Application to dye sensitized solar cells. Bulletin of the Korean Chemical Society 33(6): 1989-1992.

Kale, S.B., Lokhande, V.C., Marje, S.J., Patil, U.M., Kim, J.H. \& Lokhande, C.D. 2020. Chemically deposited $\mathrm{Co}_{3} \mathrm{~S}_{4}$ thin film: Morphology dependant electrocatalytic oxygen evolution reaction. Applied Physics A 126(3): 206-215.

Kristl, M., Dojer, B., Gyergyek, S. \& Kristl, J. 2017. Synthesis of nickel and cobalt sulfide nanoparticles using a low cost sonochemical method. Heliyon 3(3): e00273-e00273.

Lei, M., Zhang, R., Yang, H.J. \& Wang, Y.G. 2012. Synthesis of well dispersed cobalt disulfide and their photoluminescence and magnetic properties. Materials Letters 76: 87-89.

Liu, B., Kong, D., Zhang, J., Wang, Y., Chen, T., Cheng, C. \& Yang, H.Y. 2016. 3D hierarchical $\mathrm{Co}_{3} \mathrm{O}_{4} @ \mathrm{Co}_{3} \mathrm{~S}_{4}$ nanoarrays as cathode materials for asymmetric pseudocapacitors. Journal of Materials Chemistry A 4(9): 3287-3296.

Ma, X., Zhang, W., Deng, Y., Zhong, C., Hu, W. \& Han, X. 2018. Phase and composition controlled synthesis of cobalt sulfide hollow nanospheres for electrocatalytic water splitting. Nanoscale 10(10): 4816-4824.

Makuła, P., Pacia, M. \& Macyk, W. 2018. How to correctly determine the band gap energy of modified semiconductor photocatalysts based on UV-vis spectra. The Journal of Physical Chemistry Letters 9(23): 6814-6817.

Moridon, S.N.F., Salehmin, M.I., Mohamed, M.A., Arifin, K., Minggu, L.J. \& Kassim, M.B. 2019. Cobalt oxide as photocatalyst for water splitting: temperature-dependent phase structures. International Journal of Hydrogen Energy 44(47): 25495-25504.

Muradov, M.B., Balayeva, O.O., Azizov, A.A., Maharramov, A.M., Qahramanli, L.R., Eyvazova, G.M. \& Aghamaliyev, Z.A. 2018. Synthesis and characterization of cobalt sulfide nanoparticles by sonochemical method. Infrared Physics \& Technology 89: 255-262.

Nan, K., Du, H., Su, L. \& Li, C.M. 2018. Directly electrodeposited cobalt sulfide nanosheets as advanced catalyst for oxygen evolution reaction. ChemistrySelect 3(25): 7081-7088.

Ng, K.H., Minggu, L.J., Jaafar, N.A., Arifin, K. \& Kassim, M.B. 2017. Enhanced plasmonic photoelectrochemical response of Au sandwiched $\mathrm{WO}_{3}$ photoanodes. Solar Energy Materials and Solar Cells 172: 361-367.

Pawar, A.S. \& Garje, S.S. 2015. Synthesis of $\mathrm{Co}_{9} \mathrm{~S}_{8}$ and $\mathrm{CoS}$ nanocrystallites using $\mathrm{Co}$ (II) thiosemicarbazone complexes as single-source precursors. Bulletin of Materials Science 38(7): 1843-1850.

Rosman, N.N., Yunus, R.M., Minggu, L.J., Arifin, K., Salehmin, M.N.I., Mohamed, M.A. \& Kassim, M.B. 2018. Photocatalytic properties of two-dimensional graphene and layered transition-metal dichalcogenides based photocatalyst for photoelectrochemical hydrogen generation: An overview. International Journal of Hydrogen Energy 43(41): 18925-18945.

Salehmin, M.N.I., Minggu, L.J., Arifin, K., Yunus, R.M., Mohamed, M.A. \& Kassim, M.B. 2019. Recent advances on state-of-the-art copper (I/II) oxide as photoelectrode for solar green fuel generation: Challenges and mitigation strategies. Applied Catalysis A 582(117104): 1-28.

Sathre, R., Greenblatt, J.B., Walczak, K., Sharp, I.D., Stevens, J.C., Ager, J.W. \& Houle, F.A. 2016. Opportunities to improve the net energy performance of photoelectrochemical water-splitting technology. Energy \& Environmental Science 9(3): 803-819.

Staffell, I., Scamman, D., Velazquez Abad, A., Balcombe, P., Dodds, P.E., Ekins, P., Shah, N. \& Ward, K.R. 2019. The role of hydrogen and fuel cells in the global energy system. Energy \& Environmental Science 12(2): 463-491.

Sultana, U.K., He, T., Du, A. \& O’Mullane, A.P. 2017. An amorphous dual action electrocatalyst based on oxygen doped cobalt sulfide for the hydrogen and oxygen evolution reactions. RSC Advances 7(87): 54995-55004. 
Sun, W.T., Yu, Y., Pan, H.Y., Gao, X.F., Chen, Q. \& Peng, L.M. 2008. CdS quantum dots sensitized $\mathrm{TiO} 2$ nanotube-array photoelectrodes. Journal of the American Chemical Society 130(4): 1124-1125.

Wang, M., Chang, Y.S., Tsao, C.W., Fang, M.J., Hsu, Y.J. \& Choy, K.L. 2019. Enhanced photoelectrochemical hydrogen generation in neutral electrolyte using non-vacuum processed CIGS photocathodes with an earth-abundant cobalt sulfide catalyst. Chemical Communications 55(17): 2465-2468.

Wang, T., Liu, M. \& Ma, H. 2017. Facile synthesis of flower-like copper-cobalt sulfide as binder-free faradaic electrodes for supercapacitors with improved electrochemical properties. Nanomaterials 7(6): 140-150.

Yin, P.F., Sun, L.L., Gao, Y.L. \& Wang, S.Y. 2008. Preparation and characterization of $\mathrm{Co}_{9} \mathrm{~S}_{8}$ nanocrystalline and nanorods. Bulletin of Materials Science 31(4): 593-596.
Mustafid Amna Rambey, Khuzaimah Arifin*, Lorna Jeffery Minggu \& Mohammad Kassim

Fuel Cell Institute

Universiti Kebangsaan Malaysia

43600 UKM Bangi, Selangor Darul Ehsan

Malaysia

Mohammad B. Kassim

School of Chemistry Sciences and Food Technology

Faculty of Science and Technology

Universiti Kebangsaan Malaysia

43600 UKM Bangi, Selangor Darul Ehsan

Malaysia

*Corresponding author; email: khuzaim@ukm.edu.my

Received: 6 August 2020

Accepted: 11 September 2020 